\title{
THE
}

\section{The impact of digital finance on household consumption: Evidence from China}

Jie Li

Yu Wu

Jing Jian Xiao

University of Rhode Island, jjxiao@uri.edu

Follow this and additional works at: https://digitalcommons.uri.edu/hdf_facpubs

The University of Rhode Island Faculty have made this article openly available.

Please let us know how Open Access to this research benefits you.

This is a pre-publication author manuscript of the final, published article.

Terms of Use

This article is made available under the terms and conditions applicable towards Open Access Policy Articles, as set forth in our Terms of Use.

\section{Citation/Publisher Attribution}

$\mathrm{Li}$, J., Wu, Y., \& Xiao, J. J. (2020). The impact of digital finance on household consumption: Evidence from China.Economic Modelling,86, 317-326.

Available at: https://doi.org/10.1016/j.econmod.2019.09.027

This Article is brought to you for free and open access by the Human Development and Family Science at DigitalCommons@URI. It has been accepted for inclusion in Human Development and Family Science Faculty Publications by an authorized administrator of DigitalCommons@URI. For more information, please contact digitalcommons-group@uri.edu. 
Li, J., Wu, Y., \& Xiao, J. J. (2020). The impact of digital finance on household consumption: Evidence from China. Economic Modelling, 86, 317-326.

\title{
The Impact of Digital Finance on Household Consumption: Evidence from China
}

\begin{abstract}
Using panel data from the China Household Finance Survey (CHFS) in 2013, 2015, and 2017 and the digital inclusive finance index developed by Peking University, this study examined impacts of the digital inclusive finance on household consumption and explored its mechanisms. Results suggest that the digital inclusive finance could promote households consumption. A heterogeneity analysis showed that households with fewer assets, lower income, less financial literacy and in third- and fourth-tier cities experienced larger facilitating effects of digital finance on consumption compared to their counterparts. For consumption categories, digital finance was positively correlated with food, clothing, house maintenance, medical care, and education and entertainment expenditures. In terms of consumption structure, digital finance mainly promoted the recurring household expenditures rather than the non-recurring expenditures. Further analyses based on the mediating model found that online shopping, digital payment, obtainment of online credit, purchase of financing products on the internet and business insurance, were the main mediating variables through which digital finance affected household consumption.
\end{abstract}

\section{Keywords}

Digital Finance; Household Consumption; Mediating Effect

\section{JEL classification}

D12; E44; G21 


\section{Introduction}

Since China's economy entered the new normal, consumption has been gradually becoming an important driving force for economic development. In recent years, the government has been working on the expansion of residents' consumption demand. However, Chinese households' consumption behavior indicates that the consumption demand is still low. The household consumption rate has declined from $47.5 \%$ in 2000 to $35.6 \%$ in 2010 , which is far below the world average $^{1}$. Inadequate consumption has become an important restraining factor for economic transformation and sustainable development in China. How to promote the growth of household consumption has become a major subject of concern among both policy makers and the academia. Existing research on inadequate consumption has suggested that liquidity constraints (Kuijs, 2005), imperfect security systems (Meng, 2003), and income inequality (Schmidt-Hebbel and Serven, 2000) are important enforcing factors for inadequate consumption. Therefore, financial development can relieve consumers from liquidity constraints through reasonable and efficient resource allocation and realization of inter-temporal smoothing of consumption, thus increasing consumption demand (Levchenko,2005).

In recent years, with the deep integration between Internet technology and finance, the new digital finance model supported by information technology is gradually becoming an indispensable part of China's financial system as it can help decrease the degree of information asymmetry, reduce transaction costs, improve availability of financial services and optimize resource allocation in the financial market. According to the report released by a research group from the Institute of Digital Finance of Peking University in 2016, the digital inclusive finance index increased from 40 in 2011 to 220 in 2015. Digital finance has developed rapidly in just a few years. Meanwhile, the household consumption rate has picked up slightly in recent years, reaching $39.3 \%$ in 2016. Therefore, is the rapid development of digital finance able to significantly influence household consumption? Which consumer groups are most affected? How about the influence path? This paper examines these questions. Answers to these questions will not only help to understand the impacts of digital finance on China's economic development at

\footnotetext{
${ }^{1}$ According to the World Development Indicators database of World Bank, the world average consumption rate is $57.9 \%$ in 2010 .
} 
household level, but will also provide useful information on the growth of China's household consumption and a basis for improving relevant policies.

Digital finance including online loans, mobile payment, Internet finance, Internet insurance and other kinds of innovative products may impact household consumption from various aspects. First of all, online credit makes it possible to match the financial demand side with the supply side where the parties may be geographically disparate (Pierrakis and Collins, 2014). Consumption credit services represented by Alipay, cash loans and many kinds of P2P platforms and other new types of financial models have expanded the channels for obtaining funds, changed the traditional mode of credit services, lowered the bar for financial services and improved the borrowing convenience, thus relieving households from the constraints of credit to a certain extent. Then, relieving liquidity constraints promotes household consumption. Secondly, the rapidly developed Internet financing market represented by $Y u^{\prime} E B a o^{1}$ has expanded the channels for people to invest using small funds, increased the rate of return on investment and promoted the growth of household wealth, thus increasing household consumption. Meanwhile, rapidly developed digital payment platforms have greatly reduced the transaction and time costs of financial services, improved the efficiency of payment and transfer for household consumption. Additionally, the development of digital finance has not only promoted the upgrade of the service mode of traditional insurance companies, but also led to the emergence of Internet insurance companies such as Zhong'an Insurance, thus breaking the geographical barriers of the former offline outlet mode and improving insurance accessibility. Meanwhile, the application of big data technology has reduced operating costs, which may encourage residents to purchase insurance, improve residents' social security, and reduce uncertainty losses, thus increasing consumption.

This study uses panel data from the China Household Finance Survey in 2013, 2015 and 2017, and the digital inclusive finance index developed by Peking University to examine the impacts of digital finance on household consumption and further explore its mechanisms. This paper also chooses appropriate instrumental variable to solve the endogenous problem of digital finance.

\footnotetext{
${ }^{1} Y u^{\prime} E$ Bao is an internet financing product owned by Ant Financial Services Group.
} 
Results suggest that digital finance can significantly promote household consumption, especially for households with fewer assets, lower income, and less financial literacy and in third- and

fourth- tier cities, compared to their corresponding counterparts. The results of a further analysis on the influencing mechanism imply that digital finance has promoted household consumption mainly through online shopping, digital payment, obtaining loans via the Internet, purchasing financing products on the Internet, and buying commercial insurance.

The main contributions of this paper include the following. First, this paper examined Chinese families' consumption from the perspective of digital finance development, relying on the data from a nationwide large-scale household survey and the digital inclusive finance index. It has not only deepened the discussion about the problem of inadequate consumption of Chinese families, but also enriched literature relating to digital finance. Secondly, this paper reported nuanced results regarding heterogeneous impacts of digital finance on household consumption in terms of consumption structure, family characteristics, and geographical features. Thirdly, this paper made an important addition to existing literature by examining the path of influence of digital finance on household consumption using the mediating model to examine possible mechanisms of how digital finance affects household consumption through consumption channels, smoothing effects, and wealth growth effect from the aspects of online shopping, online payment, obtainment of Internet loans, and purchase of financing products on the Internet.

The remainder of this paper is arranged as follows. Section 2 reviews related literature. Section 3 introduces the data, variables, and model. Section 4 presents the results. Section 5 concludes.

\section{Literature Review}

China's household consumption demand has been low for a long time. Scholars have explained it from various perspectives. The first explanation assumes that the households are facing liquidity constraints due to the underdevelopment of the financial market and forced consumption reduction based on the theory of liquidity constraints (Kuijs, 2005; Aziz and Cui, 2007); the second explanation attributes this problem to demographic structure factors based on the life cycle hypothesis (Modigliani and Cao, 2004; Curtis et al., 2015); the third explanation assumes that the imperfect medical care, endowment, education and housing systems have intensified the 
uncertainty of residents for their future, thus strengthening the precautionary saving motivation and reducing resident consumption based on the theory of precautionary saving (Meng, 2003; Chamon and Prasad, 2010); the fourth explanation assumes that income inequality is an important reason for inadequate consumption from the perspective of income distribution (Schmidt-Hebbel and Serven, 2000; Jin et al.,2011); the fifth explanation involves cultural traditions and consumption habits (Modigliani and Cao, 2004); while the sixth explanation is the hypothesis of competitive saving (Wei and Zhang, 2011). Additionally, debts are also an important factor that affects consumption (Dynan et al., 2012; Scholnick, 2013). Many scholars had explored factors that impacted consumption growth. In terms of financial development, according to the theoretical analysis, it was believed the expansion of consumption credit services could relieve residents from liquidity constraints, thus facilitating consumption (Cochrane, 1991) and the development of the financial market could promote consumption growth (Bayoumi, 1993; Levchenko, 2005). Empirical research found that residents living in an area where the financial market was poorly developed were facing more severe liquidity constraints, whereas residents living in an area where the financial market was well developed were able to ease liquidity constraints and smooth consumption through consumption credit services (Jappelli and Pagano, 1989). Research by Ludvigson (1999) indicated that household consumption was positively correlated with consumption credit services when the qualification for consumption credit services was loosened. And the research by Karlan and Zinman (2010), and Dupas and Robinson (2013) indicated that the income and consumption of a person with low income would be increased if she sets up an account in a financial institution and used it frequently. In terms of assets and wealth, different types of assets have different impacts on household consumption and the mechanisms are also different (Carroll et al., 2001). According to the life cycle hypothesis (Ando and Modigliani, 1963), the higher the household asset level, the higher the consumption level. In terms of insurance, commercial insurance can reduce residents' uncertain expenditure in the future to some extent; purchase of insurance can help residents maintain a healthy consumption level and increase the average consumption propensity of the whole society (Arrow, 1963). Engen and Gruber (2001) proved that insurance could lower the saving ratio based on the variation of insurance coverage resulting from policy changes. Zhao (2019) also found that health insurance could increase household daily consumption. Besides, Kang (2019) found that social networks could promote household consumption. 
Existing research on digital finance focuses on its impacts on the economy, the traditional financial market, enterprise financing, and household economics and finance. In terms of the economy, research suggests that digital inclusive finance can help improve residents' income, lower poverty rates, reduce the degrees of income inequality, and narrow down the gap between urban and rural areas (Sarma and Pais, 2011; Anand and Chhikara, 2013). For the traditional financial market, the development of digital finance will transform traditional financial departments, improve the quality and diversity of banking services, and increase the efficiency of financial services (Berger, 2003; Cortina and Schmukler, 2018). In terms of financing, research indicates that big data-based risk evaluation can help save transaction cost and decrease the degree of information asymmetry, thus helping small- and micro-businesses secure financing (Moenninghoff and Wieandt, 2013). In terms of household economics and finance, a research by Beck et al. (2018) found that mobile payments could help improve entrepreneurship execution and decrease the degree of information asymmetry, thus improving entrepreneurial performance. Grossman and Tarazi (2014) found that digital finance was helpful for peasant households in Kenya through channels of convenient payment and consumption smoothing. Additionally, some researchers have discussed the inclusiveness of digital finance. Ozili (2018) argued that digital finance has a positive effect on financial inclusion and stability. Ren et al. (2018) examined the existence and degree of financial exclusion for the rural residents during the development of digital finance. They found that rural residents are excluded from both mobile payment and online borrowing. And the degree of the exclusion depends on personal characteristics, infrastructure, the social environment, and so on.

It can be seen from the above review that, as an important component of the financial market, digital finance has infiltrated all aspects of daily life. Its innovative development in online credit, Internet financing, Internet insurance, mobile payment, and credit investigation can help improve the penetrability of financial services, improve the availability of financial services to residents, relieve residents from liquidity constraints, promote income growth, facilitate residents' living consumption, thus likely promoting household consumption. However, at present, little research has examined the impacts of digital finance on consumption. Therefore, this study examined the potential impact of digital finance on household consumption based on several aspects of digital 
finance, and explored its influence path.

\section{Method}

\subsection{Data}

The household data used in this paper was obtained from the China Household Finance Survey(CHFS) carried out nationwide from 2011, by the Survey and Research Center for China Household Finance of Southwestern University of Finance and Economics. The survey is carried out every two years. Up to now, four rounds of surveys have been conducted namely, in 2011, 2013, 2015 and 2017. The survey in 2011 collected 8,438 samples from 25 provinces, municipalities, and autonomous regions, 80 counties, and 320 communities. The 2013 survey collected data from 28,143 households. The 2015 survey increased the number of samples to 37,340 households, while the 2017 increased the number of samples to 40,011 households. The surveys collected household information on demographic characteristics, assets and debts, income and consumption, and insurance and security to comprehensively reflect the conventional status of household consumption, thus providing a good data base for this study.

This paper uses unbalanced panel data composed of survey samples in 2013, 2015, and 2017. In the baseline analysis, the sample size was 66,789. In data processing, considering the possible heterogeneous consumption patterns of the young and old due to employment and physical conditions, samples of householders at the age below 18 and above 65 were excluded. Meanwhile, the consumption data, assets, and income were winsorized by eliminating samples among the top $1 \%$ and the bottom $1 \%$. Considering the abnormal fluctuations of household consumption and income, samples with household consumption variation rate (defined by the household consumption variation rate for the current year compared with that in the prior year), and household income variation rate (defined by the household income variation rate for the current year compared with that in the prior year) lower than 0 and higher than 10 were excluded. In addition, samples with missing values for relevant variables were excluded.

\subsection{Variables}

Per capita household expenditure and household consumption rate were used as dependent 
variables in this paper to measure the level of household consumption. Per capita household expenditure was defined as the value obtained by dividing the aggregate household expenditure by the number of family members. Household consumption rate was defined as the ratio obtained by dividing the aggregate household expenditure by the disposable household income. CHFS has kept a detailed record about household consumption, including expenditures for food, clothing, daily necessities and housekeeping services, house maintenance, transportation and communication, medical care, entertainment, and education, etc. Considering the possible non-normality of per capita household expenditure, these variables were transferred to logarithms in the regression.

The digital inclusive finance index developed by Peking University to reflect the development of digital finance (Guo et al., 2016), was used in this study. The index was compiled by the joint research group composed of the Institute of Digital Finance of Peking University, Shanghai Finance Institute and Ant Financial Services Group based on the big data on digital inclusive finance from Ant Financial Services. This index system covers three dimensions of digital financial services: coverage breadth, use depth, and digital support services. Under the total index, there are six categories of sub-index: payment, insurance, monetary funds, investment, credit investigation and credit. The index has three levels: province, municipality, and county. This paper mainly used the data at municipal level for regression analyses and used county level data for the robustness check. In addition, in the regression analyses, the digital finance development index that lagged two periods were adopted and all indexes were divided by 100 .

Since existing literatures listed multiple factors that impacted household consumption (Carroll, 1994; Attanasio and Weber, 1995; Zhao, 2019), the following control variables were used: household demographic characteristics namely, age and the square of age considering the possible non-linear influence, sex, marital status, education years, health condition and risk attitude of the householder; household characteristics such as family size, children's dependency ratio, and the elderly's dependency ratio. Household resource variables including household assets and income, considering the possible non-linear influence, the assets and income were transformed to logarithms. Economic development variables include per capita GDP and financial development level measured by the ratio of outstanding loans in RMB of financial 
institutions to GDP of the province where the family was located. Additionally, dummy variables of provinces were included to control provincial fixed effects. The detailed variable descriptions are shown in Table 1.

\section{[INSERT TABLE 1 ABOUT HERE]}

The descriptive statistics of the main variables are shown in Table 2. As seen in the table, on average, the per capita household consumption expenditure is RMB 18,750, the total index of digital finance development is 1.327. For the years of 2013, 2015, and 2017 respectively, the average amounts of per capita household consumption were RMB 16,440, 18,980, and 20,550, while the total index of digital finance development were $0.588,1.431$, and 1.871 .

\section{[INSERT TABLE 2 ABOUT HERE]}

\subsection{Model}

In the basic regression, the dependent variables were continuous variables. Therefore, the OLS model was used as follows:

$$
\text { COMSUMP }_{i t}=\alpha+\beta_{1} \times \text { INDEX }_{i t_{-2}}+\beta_{2} \times X_{i t}+\delta_{t}+\varepsilon_{i t}
$$

In the above equation, COMSUMP it represents the dependent variable: per capita consumption expenditure of household $\mathrm{i}$ in year t. Additionally, the household consumption rate is used as an alternative dependent variable in the robustness examination. INDEX $\mathrm{it}_{\mathrm{it}} 2$ represents the digital finance development index of year $t_{-2}$ in the area where household $i$ is located and is used to measure the level of digital finance development in this city. $\beta 1$ is the corresponding regression coefficient, representing the marginal effect of digital finance development on per capita household consumption expenditure. $X_{\text {it }}$ represents a series of control variables, including householder characteristics, household wealth, regional economic development, etc. $\delta$ trepresents time fixed effect. $\varepsilon_{\text {it }}$ is a random disturbing term. 
Previous studies show that the development of the financial market (Levchenko, 2005), improvement of security level (Engen and Gruber, 2001) and convenient payment (McCallum and Goodfriend, 1988) can facilitate household consumption. In addition, online shopping arising with the rapid development of e-commerce has decreased the degree of information asymmetry and expanded supply in the consumer market, thus likely influencing household consumption purchase decisions. Since digital finance has infiltrated many aspects of daily life, this study explored the mechanism by which digital inclusive finance affects household consumption from the aspects of online shopping, online payment, online credit, internet financing, and commercial insurance, with the meditating model for examination. What needs to be noted is that, since variables relating to online payment and online credit in the CHFS data were inquired only in 2017, and the inquiry on online shopping in 2013 and 2017 was "did your family shop online last year," while that in 2015 was "did your family shop online last month," making the data incomparable. Only the cross-section data in 2017 were used for the analyses in this part. The mediating model was set as follows (Baron and Kenny, 1986):

$$
\begin{aligned}
& \log (\text { comsump })_{i}=\beta_{0}+\beta_{1} \times \text { Index }_{i}+\beta_{2} \times X_{i}+\varepsilon_{i} \\
& \text { Internet }_{i}=\alpha_{0}+\alpha_{1} \times \text { Index }_{i}+\alpha_{2} \times X_{i}+\varepsilon_{i} \\
& \log (\text { comsump })=\lambda_{0}+\lambda_{1} \times \text { Index }_{i}+\lambda_{2} \times \text { Internet }_{i}+\lambda_{3} X_{i}+\varepsilon_{i}
\end{aligned}
$$

The first step is to perform a regression on Model 2. Coefficient $\beta_{1}$ measures the total effect of the digital inclusive finance index on per capita household consumption expenditure. The second step is to perform a regression on Model 3. Coefficient $\alpha_{1}$ measures the effect of the index of digital inclusive finance on mediating variables (if significant, it means that digital inclusive finance has explained the variation of mediating variables). The third step is to perform a regression on Model 4. Coefficient $\lambda_{2}$ measures the effect of mediating variables on household consumption after controlling the digital inclusive finance independent variable. If in the regression results of Model $4, \lambda_{1}$ and $\lambda_{2}$ are significant and have the symbols as expected and the value of $\lambda_{1}$ is lower than $\beta_{1}$, it means that there exists a certain degree of mediating effect; if $\lambda_{1}$ is insignificant, but $\lambda_{2}$ is still significant, it means that the mediating variable has played 
the role of a full mediator.

\section{Empirical Results}

\subsection{Baseline results}

Based on the examination results from the Hausman Test, the values of $p$ is 0.000 , which significantly reject the null hypothesis, thus this part adopts the fixed effect model to examine the impacts of the development of digital finance on household consumption expenditures. Table 3 reports the baseline regression results. The first column shows the regression results of the total index of digital finance. As shown in the table, the regression coefficient of digital finance on per capita household expenditure is significantly positive at a magnitude of 0.108 , which indicates that digital finance has significantly promoted household consumption.

However, there is possible endogenous problem caused by a reverse causality issue. To overcome this problem, we use the number of mobile phones per person in the province as the instrumental digital finance variable. On the one hand, mobile phones have facilitated the use of financial services by residents, and can therefore be correlated with the level of digital finance development in a place. On the other hand, the average number of mobile phones in provinces hardly affects the consumption expenditure of households. Besides, we also did some tests to verify the validity of the instrumental variable. As shown in the second column of Table 3 , in the regression results of first stage, the $t$ value of the instrumental variable is 142.94, which is significantly positive at the $1 \%$ level, so it can be considered that the instrumental variable meets the requirements of correlation. The value of the $\mathrm{F}$ statistic estimated in the first stage is 56268.28, indicating that there is no weak instrumental variable problem. Endogeneity test

rejects the null hypothesis which means that there is an endogenous problem of digital finance. The coefficient of digital finance is still significantly positive.

For the control variables, the coefficients of total household assets and total household income are significantly positive, which indicates that the higher the household assets and income level, the higher the household consumption level and is consistent with the hypothesis of permanent income and inter-temporal consumption smoothing under the life cycle hypothesis. The regional 
financial development also has positive impacts on the level of household consumption, suggesting that regional financial development may promote household consumption.

Since digital finance is a multi-dimensional concept, this paper not only examined the impacts of the total index of digital finance on household expenditure, but also used second-level and third-level indices in the regression analyses. The second-level indices are coverage breadth, and use depth, and the regression results are shown in the second and third columns of Table 3; the third-level indexes namely, insurance, investment, credit investigation and the regression results are shown in the fourth, fifth, and sixth columns in Table 3. The results indicate that all the sub-indexes including coverage breadth and depth of digital finance use, have significantly positive impacts on household consumption. The coefficients are $0.216,0.060,0.016,0.328$, 0.357 respectively. It indicates that digital finance can effectively promote household consumption in both coverage and use. In terms of the third-level index, the coefficient of insurance index is significantly positive, implying that digital finance in the area of insurance can facilitate the obtainment of household insurance services and reduce uncertain household expenditures, thus promoting household consumption; the coefficient of investment index is also significantly positive, suggesting that digital finance can expand the channels for residents to invest, improve the return on investment and facilitate the growth of household income, thus improving the level of household consumption; credit investigation index also has significantly positive impacts on household consumption, indicating that digital finance can promote the development of online credit investigation, help improve the availability of online credit to residents and relieve the liquidity constraints, thus promoting consumption. Therefore, digital finance can lower the threshold of financial services and improve the availability of household financial services through diversified financial products, thus promoting the growth of household consumption.

\section{[INSERT TABLE 3 ABOUT HERE]}

\subsection{Heterogeneity results}

This section reports the heterogeneity of the impacts of digital inclusive finance on household 
consumption among families in terms of household assets, household income, householder's financial literacy level, and urban development level, and the regression results are shown in Table 4. For a more reasonable division of the household sample, the balanced panel data was used in the regression for asset, income, and financial literacy heterogeneity, means these households selected existed in 2013, 2015, and 2017. First, the samples were classified into two types: families with more assets and those with fewer assets. According to the regression results reported in the first column, the interaction coefficient between digital finance index and families with fewer assets was 0.061 which is significantly positive, suggesting that the facilitating effect of the development of digital finance on household expenditure is greater in families with fewer assets. Secondly, the samples were classified into two categories: families with higher income and those with lower income. According to the results reported in the second column, the coefficient of interaction between digital finance index and families with lower income is significantly positive at a magnitude of 0.067 , implying that digital finance has a larger facilitating effect on the consumption of families with lower income. The third column shows the regression results of the difference in the financial literacy levels. After categorizing the samples into families with higher and those with lower financial literacy levels based on householder's financial literacy level, the results show that the coefficient of interaction between digital finance index and families with lower financial literacy level is 0.039 , which is significantly positive, suggesting that digital finance has a larger facilitating effect on consumption in families in which heads have lower financial literacy levels. Finally, the samples were classified into families residing in first- and second-tier cities and those residing in third- and fourth-tier cities. The regression results are shown in the fourth column of Table 4. The coefficient of interaction of digital finance index and families in third- and fourth-tier cities is 0.046, which is also significantly positive, indicating that digital finance has larger impacts on the household consumption of families in third- and fourth-tier cities than in households living in first- and second-tier cities. The possible interpretation for the above results is that, in comparison to families with fewer assets, low income and lower financial literacy levels, and in third- and fourth- tier cities, families with more assets, high income and higher financial literacy levels and in first- and second-tier cities are facing less liquidity constraints, thus being less influenced by the marginal effect of digital finance on consumption. 


\section{[INSERT TABLE 4 ABOUT HERE]}

We further discuss the heterogeneous impacts of digital finance on eight categories of household consumption and the results are shown in Table 5. The results show that the facilitating effects of digital finance on household consumption still exists significantly in five consumption categories (food, clothing, house maintenance, medical care, and entertainment and education). And the estimated coefficients are $0.098,0.663,0.140,0.454,2.618$, respectively. Note that the coefficient of entertainment and education is the largest, which may be because consumption elasticity of entertainment is relatively large and more easily being influenced.

\section{[INSERT TABLE 5 ABOUT HERE]}

Additionally, expenditures for travel, durables, medical care, study abroad, luxuries, home repairs and extension belong to non-recurring household consumption while expenditures for food, clothing, daily necessities, transportation and communication, entertainment and others belong to recurring household consumption, this paper also performed regression analyses on both types of consumption expenditures. The results are shown in Table 6. According to the regression results, the digital inclusive finance index has significantly promoted the growth of recurring household consumption expenditures as well as the proportion of recurring consumption expenditures, which indicates that digital inclusive finance has more facilitating

effects on the household expenditure for a basic livelihood household. This may be because digital finance promotes the development of online shopping, which promotes the daily household consumption.

\section{[INSERT TABLE 6 ABOUT HERE]}

\subsection{Mechanism results}

This section explored possible mechanisms by which digital finance affects household consumption. With the development of e-commerce, online shopping channels can help households improve the convenience of shopping and obtain abundant and cost-efficient 
commodities, thus likely promoting consumption. Table 7 reports the effects of the digital finance for which online shopping was selected as the mediating variable for household consumption. The results in the second column show that the coefficient of the impact of the digital finance index on household online shopping is positive, indicating that digital finance has promoted household online shopping. The results in the third column show that household online shopping has a significantly positive impact on household consumption. Meanwhile, after adding the variable of online shopping, the coefficient of the impact of the index of digital inclusive finance on household consumption is still significantly positive and its value is lower than the regression coefficient in the first column, suggesting that online shopping has a certain mediating effect. The results of the Sobel mediating effect test show that the effect of online shopping as a mediating variable is significant at $8.37 \%$, implying that $8.37 \%$ of the effect of digital finance on household consumption is through the promotion of households online purchase.

\section{[INSERT TABLE 7 ABOUT HERE]}

The development of digital finance has led to the rapid development of online payment, greatly reduced the transaction and time cost of financial services, increased the efficiency of payment and transfer of household consumption and facilitated residents' consumption. Table 8 reports the regression results for which online payment is selected as the mediating variable through which the digital finance affects household consumption. The results in the second column show that the coefficient of the impact of the index of digital finance on online payment is significantly positive, implying that digital finance has significantly promoted the use of digital payment. The

results in the third column show that digital payment has a positive impact on per capita household expenditure. Meanwhile, after controlling the variable of online payment, the coefficient of the index of digital inclusive finance is still significantly positive and its value is a little lower than the result in the first column, suggesting that online payment is a mediating variable through which digital inclusive finance affects household consumption. The result of the Sobel mediating effect test also supports the result. The meditating effect of digital payment accounts for $10.58 \%$ of the total effect of digital finance on household consumption. 
Liquidity constraints are an important factor that restricts household consumption (Aziz and Cui, 2007). The development of online credit under digital finance can relieve consumers from the constraints of micro loans, thus likely promoting household consumption. Table 9 reports the results for which online credit is selected as the mediating variable through which the development of digital finance affects household consumption. The results in the second column show that the coefficient of the impacts of the index of digital finance on access to online credit is significantly positive, which indicates that digital finance has improved the access to online credit in households. The findings in the third column show that the access to online credit has significant positive impacts on household expenditure. Meanwhile, the coefficient of the index of digital finance is significantly positive and slightly lower than the result in the first column, implying that access to online credit is a mediating variable through which digital finance affects household consumption. The result of the Sobel mediating effect test is also significant at a magnitude of $1.91 \%$, which supports the conclusion.

\section{[INSERT TABLE 9 ABOUT HERE]}

The value-added effect of digital finance on household consumption is delivered mainly through a wealth and income effect and realized through Internet financing (Zhang and Tu,2017). Digital

finance has expanded the investment channels for residents. Internet financing products with both good profitability and liquidity represented by "Yu'e Bao" can promote household Internet investment and increase the rate of return on investment made by residents, thus likely promoting household consumption. Table 10 reports the results of Internet financing as a mediating variable. The results in the second column show that the index of digital finance has significantly positive impacts on the purchase of Internet financing products, which indicates that digital finance can effectively promote the participation of households in the Internet financing market. The results in the third column show that the coefficient of the impacts of the purchase of Internet financing products on per capita household expenditure is significantly positive, and the coefficient of the index of digital finance is still significantly positive but slightly reduced compared with the result in the first column. It means that the purchase of Internet financing products is a mediating variable through which digital finance affects household consumption. 
The result of the Sobel mediating effect test shows that the mediating effect of internet financing is significant at $2.22 \%$.

\section{[INSERT TABLE 10 ABOUT HERE]}

Since China's social security system is presently imperfect, there are higher uncertainty risks in households. Commercial insurance can help reduce the household expenditures on uncertainty risks like diseases and accidents, thus likely promoting household consumption. With the support of big data and information technology, the launching of more and more products online by traditional insurance companies and the gradual rise of Internet insurance may also promote more convenient insurance purchase by households. Table 11 reports the results of the mediating effect of commercial insurance purchase. The results in the second column show that the coefficient of the index of digital finance on the probability of households purchasing commercial insurance is significantly positive, which indicates that digital finance has promoted the purchase of insurance by households. The results in the third column show that the coefficient of the effect of the purchase of commercial insurance on per capita household expenditure is significantly positive. And, the coefficient of the index of digital inclusive finance is smaller than the first column, which indicates that insurance purchase plays a mediating role in the relationship between digital finance and household consumption. However, the results of the Sobel mediating effect test is significant at only $0.83 \%$ mediating effect, which is much weaker than in the other mediating variables.

\section{[INSERT TABLE 11 ABOUT HERE]}

\subsection{Robustness checks}

This section performed a robustness check using the index of digital inclusive finance at the county level as the alternate index for digital finance development and the household consumption rate as the measure of household consumption level. The regression results are shown in Table 12 and Table 13. Since the digital finance indices at the county level are only for 2014, only the household samples for 2017 were selected in the regression. In Table 12, the first 
column shows the impacts of the total index of digital finance on per capita household expenditure; the second column shows the impacts of the index of digital finance coverage breadth on per capita household expenditure; the third column shows the impacts of the index of digital finance use depth on per capita household expenditure; the fourth column shows the impacts of the index of insurance on per capita household expenditure; the fifth column shows the impacts of the index of investment on per capita household expenditure; and the sixth column shows the impacts of the index of credit investigation on per capita household expenditure. It can be seen that the regression coefficients of all indices of digital finance are significantly positive, which indicates that the higher the digital finance development level, the higher the household consumption expenditure; and that digital finance has significantly promoted household consumption, consistent with the results in previous sections.

\section{[INSERT TABLE 12 ABOUT HERE]}

Table 13 reports the impacts of the index of digital inclusive finance on household consumption rate. The first, second, third, fourth, fifth and sixth columns report the regression results of the total index of digital inclusive finance and the indexes of coverage breadth, use depth, insurance, investment and credit investigation on household consumption rate, respectively. It can be seen that the coefficients of all indexes of digital finance are significantly positive, which indicates that the digital finance has significantly promoted the household consumption rate, consistent with the results before mentioned.

\section{[INSERT TABLE 13 ABOUT HERE]}

\section{Conclusion}

In recent years, there has been rapid development of digital finance based on big data, cloud computing and other digital technologies. By combining the data of CHFS and the digital finance index, this study performed empirical analyses on the impacts of digital finance on household consumption and explored its influencing mechanisms. 
The results show that digital finance can significantly promote household consumption, especially for recurring items and households with fewer assets, lower income, less financial literacy, and those that live in third- and fourth-tier cities. The mediating model suggest that online shopping, digital payment, access to online credit, purchase of financing products on the internet and commercial insurance are all mediating variables in the relationship between digital finance and household consumption, which indicate the impacts of digital finance on household consumption mainly through relieving liquidity constrain, facilitating payment and transaction, expanding investment channels and increasing income, and enhancing security. Relevant government agencies shall actively promote the development of digital finance and focus on the role of digital finance in improving the consumption level of low- and middle-income families and underdeveloped areas. 


\section{References}

Anand, S.K., and Chhikara, K. S. (2013). A theoretical and quantitative analysis of financial inclusion and economic growth. Management and Labour Studies,38(1-2), 103-133.

Ando, A., and Modigliani, F. (1963). The "Life Cycle" hypothesis of saving: aggregate implications and tests. American Economic Review, 53(1),55-84.

Arrow, K. J. (1964). The role of securities in the optimal allocation of risk-bearing. Review of Economic Studies, 31(2), 91-96.

Attanasio, O. P. , \& Weber, G. . (1995). Is consumption growth consistent with intertemporal optimization? evidence from the consumer expenditure survey. Journal of Political Economy, 103(6), 1121-1157.

Aziz,M.J., and Cui, L.(2007). Explaining China's low consumption: the neglected role of household income. International Monetary Fund,7-181.

Baron, R. M., and Kenny, D. A. (1986). The moderator-mediator variable distinction in social psychological research: Conceptual, strategic, and statistical considerations. Journal of Personality and Social Psychology, 51, 1173-1182.

Bayoumi, T. (1993). Financial deregulation and consumption in the UK. Review of Economics and Statistics,75,1121 $-1130$.

Beck, T., Pamuk, H., Ramrattan, R., and Burak, R. U. (2018).Payment instruments, finance and development. Journal of Development Economics, 133,162-186.

Berger, A. N. (2003). The economic effects of technological progress: evidence from the banking industry. Journal of Money, Credit and Banking, 35(2),141-176.

Carroll, C. D. (1994). How does future income affect current consumption?. The Quarterly Journal of Economics, 109(1), 111-147.

Carroll, C. D., and Kimball, M. S. (2001). Liquidity Con-straints and Precautionary Saving". NBER Working Paper, No.8496.

Chamon,M. D., and Prasad, E.S. (2010). Why are saving rates of urban households in China rising. American Economic Journal: Macroeconomics,2(1),93-130.

Cochrane, J.H. (1991). A simple test of consumption insurance. Journal of Political Economy, 99( 5), 957-976.

Cortina Lorente, J. J. , and Schmukler, S. L. (2018). The fintech revolution: a threat to global banking?. Research and Policy Briefs.

Curtis, C. C. , Lugauer, S. , and Mark, N. C. . (2015). Demographic patterns and household saving in China. American Economic Journal: Macroeconomics, 7(2), 58-94.

Dupas, P. , and Robinson, J. (2013). Why don't the poor save more? evidence from health savings experiments. American Economic Review, 103(4), 1138-1171.

Dynan, K. E. (2012). Is a household debt overhang holding back consumption?. Brookings Papers on Economic Activity,345-351.

Engen, E. M. , and Gruber, J. (2001).Unemployment insurance and precautionary saving. Journal of Monetary Economics, 47(3),545-545. 
Grossman, J., and Tarazi, M. (2014). Serving smallholder farmers : recent developments in digital finance. Focus Note, 94.

Guo,F., Kong, T., Wang, J. Y., Zhang, X.,Cheng, Z. Y.,Ruan, F.Y., Sun,T.,Wang,F. (2016). The index system and compilation of Chinese digital inclusive finance. Working paper of Institute of Digital Finance, Peking University.

Hall, and Robert, E. (1978). Stochastic implications of the life cycle-permanent income hypothesis: theory and evidence. Journal of Political Economy, 86(6), 971-987.

Jappelli, T. , and Pagano, M. . (1989). Consumption and capital market imperfections: an international comparison. American Economic Review, 79(5), 1088-1105.

Jin, Y. , Wu, B. , and Li, H. . (2011). Income inequality, consumption, and social-status seeking, Journal of Comparative Economics, 39(2),191-204.

Kang, X. (2019). The Impact of Family Social Network on Household Consumption. Modern Economy,10(3),679-697.

Karlan, D. S., and Zinman, J.(2010). Expanding credit access: using randomized supply decisions to estimate the impacts. Review of Financial Studies,23(1) ,433-464.

Kuijs, L. (2005). Investment and saving in china. Policy Research Working Paper Series, 1-20.

Levchenko, A. A. (2005). Financial liberalization and consumption volatility in developing countries. IMF Economic Review, 52(2), 237-259.

Ludvigson, S. (1999). Consumption and credit: a model of time-varying liquidity constraints. The Review of Economics and Statistics, 81(3), 434-447.

Meng, X. (2003). Unemployment, consumption smoothing, and precautionary saving in urban China. Journal of Comparative Economics, 31(3), 465-485.

Modigliani, F. , and Cao, S. L. (2004). The chinese saving puzzle and the life-cycle hypothesis. Journal of Economic Literature, 42(1), 145-170.

Moenninghoff, S. C. , and Wieandt, A.(2013) The Future of Peer-to-Peer Finance. Schmalenbachs Zeitschrift fur betriebswirtschaftliche Forschung, 65(6), 466-487.

Ozili, P. K. (2018). Impact of digital finance on financial inclusion and stability. Borsa Istanbul Review,18(4),329-340.

Pierrakis, Y. , and Collins, L. (2013). Crowdfunding: a new innovative model of providing funding to projects and businesses. Ssrn Electronic Journal.

Ren, B., Liuying, L. I., Zhao, H., and Zhou, Y. (2018). The financial exclusion in the development of digital finance - a study based on survey data in the jingjinji rural area. Singapore Economic Review, 63(01), 65-82.

Sarma,M., and Pais,J. (2008). Financial inclusion and development: a cross country analysis. Annual Conference of the Human Development and Capability Association,New Delhi.

Schmidt-Hebbel, K. , and Luis Servén. (2000). Does income inequality raise aggregate saving? Journal of Development Economics, 61(2), 417-446.

Scholnick, B. (2013). Consumption smoothing after the final mortgage payment: testing the magnitude 
hypothesis. The Review of Economics and Statistics, 95(4), 1444-1449.

Wei,S.J., and Zhang, X. (2011). The competitive saving motive: evidence from rising sex ratios and savings rates in China. Journal of Political Economy,119( 3) ,511-564.

Zhao, W. M.(2019). Does health insurance promote people's consumption? New evidence from China. China Economic Review,53,65-86. 
Table 1. Variable definition

\begin{tabular}{|c|c|}
\hline Variables & Definition \\
\hline $\begin{array}{l}\text { Per capita household } \\
\text { Consumption }\end{array}$ & $\begin{array}{l}\text { The value obtained by dividing the aggregate household expenditure by the number of family } \\
\text { members }\end{array}$ \\
\hline Household consumption rate & $\begin{array}{l}\text { The ratio obtained by dividing the aggregate household expenditure by the disposable household } \\
\text { income }\end{array}$ \\
\hline Household total asset & Household total asset \\
\hline Household total income & Household total income \\
\hline Hhead_age & Householder age \\
\hline Hhead_male & Householder gender, male: 1 ,female: 0 \\
\hline Hhead_edu_years & $\begin{array}{l}\text { Householder education years, no education:0, primary school:6, junior high school:9, senior high } \\
\text { school/ professional high school:12, junior college/ higher vocational school:15, } \\
\text { undergraduate: } 16 \text {, postgraduate: } 19 \text {. }\end{array}$ \\
\hline Hhead_married & Householder marital status,married: 1 ,others:0 \\
\hline House_member_size & Family size \\
\hline Child_ratio & $\begin{array}{l}\text { The ratio of the number of population at the age of } 0 \sim 15 \text { years old to the number of labor } \\
\text { population at the age of } 16 \sim 65 \text { years old in the household }\end{array}$ \\
\hline Elder_ratio & $\begin{array}{l}\text { The ratio of the number of population at the age above } 65 \text { years old to the number of labor } \\
\text { population at the age of } 16 \sim 65 \text { years in the household }\end{array}$ \\
\hline Risk_prefer & Risk attitude of the householder, risk seeker: 1 ,others: 0 \\
\hline Risk_averse & Risk attitude of the householder, risk aversion: 1 , others: 0 \\
\hline Unhealthy members & The number of unhealthy household member \\
\hline Rural & Rural:1,city:0 \\
\hline Per_gdp & Per capita GDP \\
\hline Financial development level & The ratio of outstanding loans in RMB of financial institutions to GDP of the province \\
\hline Online shopping & Whether shopping online, yes: 1, no:0 \\
\hline Digital payment & Whether using digital payment,yes:1,no:0 \\
\hline Online credit & Whether obtaining credit on the internet, yes: 1, no: 0 \\
\hline Online_fpp & Whether purchasing financing products on the internet,yes:1,no:0 \\
\hline Busi_insurance & Whether purchasing business insurance,yes:1,no:0 \\
\hline
\end{tabular}


Table 2. Data description

\begin{tabular}{|c|c|c|c|c|c|c|c|c|c|c|c|c|}
\hline & \multicolumn{3}{|c|}{ 2013-2017 } & \multicolumn{3}{|c|}{2013} & \multicolumn{3}{|c|}{2015} & \multicolumn{3}{|c|}{2017} \\
\hline & Obs & Mean & Std. & Obs & Mean & Std. & Obs & Mean & Std. & Obs & Mean & Std. \\
\hline Per capita household & & & & & & & & & & & & \\
\hline $\begin{array}{l}\text { Consumption(ten } \\
\text { thousand yuan) }\end{array}$ & 66789 & 1.875 & 2.351 & 20307 & 1.644 & 1.985 & 23412 & 1.898 & 2.514 & 23070 & 2.055 & 2.458 \\
\hline $\begin{array}{l}\text { Household } \\
\text { consumption rate }\end{array}$ & 37705 & 0.539 & 0.236 & 11200 & 0.538 & 0.240 & 12488 & 0.542 & 0.236 & 14017 & 0.538 & 0.232 \\
\hline $\begin{array}{l}\text { Digital inclusive } \\
\text { finance index }\end{array}$ & 66789 & 1.327 & 0.569 & 20307 & 0.588 & 0.178 & 23412 & 1.431 & 0.248 & 23070 & 1.871 & 0.242 \\
\hline $\begin{array}{l}\text { Index of coverage } \\
\text { breadth }\end{array}$ & 66789 & 1.302 & 0.596 & 20307 & 0.616 & 0.289 & 23412 & 1.342 & 0.328 & 23070 & 1.865 & 0.337 \\
\hline Index of use depth & 66789 & 1.239 & 0.494 & 20307 & 0.605 & 0.180 & 23412 & 1.449 & 0.294 & 23070 & 1.584 & 0.270 \\
\hline $\begin{array}{l}\text { Household total } \\
\text { asset(ten thousand } \\
\text { yuan) }\end{array}$ & 66789 & 101.352 & 203.317 & 20307 & 77.718 & 148.118 & 23412 & 99.169 & 216.271 & 23070 & 124.373 & 227.760 \\
\hline $\begin{array}{l}\text { Household total } \\
\text { income(ten thousand } \\
\text { yuan) }\end{array}$ & 66789 & 8.354 & 13.286 & 20307 & 6.887 & 11.151 & 23412 & 8.162 & 14.131 & 23070 & 9.841 & 13.957 \\
\hline Hhead_age & 66789 & 47.045 & 10.552 & 20307 & 45.694 & 10.604 & 23412 & 46.955 & 10.514 & 23070 & 48.325 & 10.389 \\
\hline Hhead_male & 66789 & 0.779 & 0.415 & 20307 & 0.773 & 0.419 & 23412 & 0.771 & 0.420 & 23070 & 0.792 & 0.406 \\
\hline Hhead_edu_years & 66789 & 10.047 & 3.846 & 20307 & 9.876 & 3.899 & 23412 & 10.064 & 3.844 & 23070 & 10.181 & 3.797 \\
\hline Hhead_married & 66789 & 0.841 & 0.366 & 20307 & 0.886 & 0.318 & 23412 & 0.804 & 0.397 & 23070 & 0.838 & 0.369 \\
\hline House_member_size & 66789 & 3.811 & 1.646 & 20307 & 3.711 & 1.520 & 23412 & 3.814 & 1.634 & 23070 & 3.896 & 1.757 \\
\hline Child_ratio & 66789 & 0.246 & 0.356 & 20307 & 0.258 & 0.365 & 23412 & 0.246 & 0.355 & 23070 & 0.235 & 0.348 \\
\hline Elder_ratio & 66789 & 0.166 & 0.377 & 20307 & 0.177 & 0.396 & 23412 & 0.165 & 0.373 & 23070 & 0.157 & 0.364 \\
\hline Risk_prefer & 66789 & 0.121 & 0.326 & 20307 & 0.126 & 0.332 & 23412 & 0.116 & 0.321 & 23070 & 0.122 & 0.327 \\
\hline Risk_averse & 66789 & 0.648 & 0.477 & 20307 & 0.630 & 0.483 & 23412 & 0.668 & 0.471 & 23070 & 0.645 & 0.478 \\
\hline Unhealthy members & 66789 & 0.279 & 0.573 & 20307 & 0.286 & 0.565 & 23412 & 0.298 & 0.601 & 23070 & 0.254 & 0.549 \\
\hline Rural & 66789 & 0.302 & 0.459 & 20307 & 0.328 & 0.470 & 23412 & 0.290 & 0.454 & 23070 & 0.290 & 0.454 \\
\hline Per_gdp & 66789 & 5.857 & 2.465 & 20307 & 5.059 & 2.142 & 23412 & 5.775 & 2.222 & 23070 & 6.644 & 2.712 \\
\hline $\begin{array}{l}\text { Financial } \\
\text { development level }\end{array}$ & 66789 & 1.351 & 0.422 & 20307 & 1.219 & 0.420 & 23412 & 1.360 & 0.400 & 23070 & 1.458 & 0.414 \\
\hline Online shopping & & & & - & - & - & - & - & - & 23070 & 0.538 & 0.499 \\
\hline Digital payment & & & & & & & - & - & & 23070 & 0.406 & 0.491 \\
\hline Online credit & - & - & - & - & - & - & - & - & - & 23070 & 0.076 & 0.265 \\
\hline Online_fpp & & & & & & & - & - & $\longrightarrow$ & 23070 & 0.111 & 0.315 \\
\hline Busi_insurance & - & - & - & - & - & - & - & - & - & 23070 & 0.192 & 0.394 \\
\hline
\end{tabular}


Table 3. the Impact of the Digital Finance on Household Consumption

\begin{tabular}{|c|c|c|c|c|c|c|c|}
\hline & (1) & (2) & (3) & (4) & (5) & (6) & (7) \\
\hline \multirow{2}{*}{$\begin{array}{l}\text { Total index of } \\
\text { digital finance }\end{array}$} & $0.108^{* * * *}$ & $0.139^{* * * *}$ & & & & & \\
\hline & $(0.033)$ & $(0.038)$ & & & & & \\
\hline Index of coverage & & & $0.216^{* * *}$ & & & & \\
\hline & & & $(0.055)$ & & & & \\
\hline Index of use depth & & & & $\begin{array}{c}0.060^{* * *} \\
(0.019)\end{array}$ & & & \\
\hline Index of insurance & & & & & $\begin{array}{l}0.016^{* * * *} \\
(0.005)\end{array}$ & & \\
\hline Index of investment & & & & & & $\begin{array}{c}0.328^{* * *} \\
(0.071)\end{array}$ & \\
\hline $\begin{array}{l}\text { Index of credit } \\
\text { investigation }\end{array}$ & & & & & & & $0.357^{* * * *}$ \\
\hline $\operatorname{Ln}$ (asset) & $\begin{array}{c}0.079^{* * * *} \\
(0.005)\end{array}$ & $\begin{array}{l}0.080^{* * * *} \\
(0.003)\end{array}$ & $\begin{array}{l}0.079^{* * *} \\
(0.005)\end{array}$ & $\begin{array}{c}0.079^{* * *} \\
(0.005)\end{array}$ & $\begin{array}{l}0.080^{* * * *} \\
(0.005)\end{array}$ & $\begin{array}{c}0.122^{* * * *} \\
(0.007)\end{array}$ & $\begin{array}{l}(0.042) \\
0.119^{* * * *} \\
(0.006)\end{array}$ \\
\hline Ln(income) & $\begin{array}{c}0.028^{* * * *} \\
(0.002)\end{array}$ & $\begin{array}{l}0.028^{* * * *} \\
(0.002)\end{array}$ & $\begin{array}{l}0.028^{* * *} \\
(0.002)\end{array}$ & $\begin{array}{l}0.028^{* * *} \\
(0.002)\end{array}$ & $\begin{array}{c}0.028^{* * *} \\
(0.002)\end{array}$ & $\begin{array}{l}0.076^{* * *} \\
(0.005)\end{array}$ & $\begin{array}{l}0.075^{* * * *} \\
(0.005)\end{array}$ \\
\hline Hhead_age & $\begin{array}{c}-0.059^{* * * *} \\
(0.015)\end{array}$ & $\begin{array}{c}-0.069^{* * * *} \\
(0.016)\end{array}$ & $\begin{array}{c}-0.086^{* * * *} \\
(0.017)\end{array}$ & $\begin{array}{c}-0.042^{* * *} \\
(0.013)\end{array}$ & $\begin{array}{c}-0.035^{* * * *} \\
(0.012)\end{array}$ & $\begin{array}{c}-0.030^{* * * *} \\
(0.005)\end{array}$ & $\begin{array}{c}-0.028^{* * * *} \\
(0.005)\end{array}$ \\
\hline square of age & $\begin{array}{l}0.022^{* * *} \\
(0.010)\end{array}$ & $\begin{array}{l}0.022^{* *} \\
(0.009)\end{array}$ & $\begin{array}{l}0.022^{* *} \\
(0.010)\end{array}$ & $\begin{array}{l}0.022^{* *} \\
(0.010)\end{array}$ & $\begin{array}{l}0.022^{* *} \\
(0.010)\end{array}$ & $\begin{array}{l}0.022^{* * *} \\
(0.005)\end{array}$ & $\begin{array}{l}0.020^{* * * *} \\
(0.005)\end{array}$ \\
\hline Hhead_male & $\begin{array}{c}0.336^{* * *} \\
(0.170)\end{array}$ & $\begin{array}{c}0.310 \\
(0.313)\end{array}$ & $\begin{array}{c}0.265 \\
(0.238)\end{array}$ & $\begin{array}{l}0.383^{* *} \\
(0.151)\end{array}$ & $\begin{array}{l}0.399^{* * * *} \\
(0.151)\end{array}$ & $\begin{array}{c}-0.050^{* * * *} \\
(0.010)\end{array}$ & $\begin{array}{c}-0.047^{* * * *} \\
(0.010)\end{array}$ \\
\hline Hhead_edu_years & $\begin{array}{l}-0.186^{* * *} \\
(0.079)\end{array}$ & $\begin{array}{c}-0.224^{* * *} \\
(0.116)\end{array}$ & $\begin{array}{c}-0.308^{* * *} \\
(0.099)\end{array}$ & $\begin{array}{l}-0.109 \\
(0.072)\end{array}$ & $\begin{array}{l}-0.079 \\
(0.073)\end{array}$ & $\begin{array}{l}0.020^{* * *} \\
(0.002)\end{array}$ & $\begin{array}{l}0.020^{* * * *} \\
(0.002)\end{array}$ \\
\hline Hhead_married & $\begin{array}{c}0.356 \\
(0.771)\end{array}$ & $\begin{array}{c}0.371 \\
(1.045)\end{array}$ & $\begin{array}{c}0.397 \\
(0.760)\end{array}$ & $\begin{array}{c}0.333 \\
(0.805)\end{array}$ & $\begin{array}{c}0.300 \\
(0.822)\end{array}$ & $\begin{array}{l}-0.010 \\
(0.014)\end{array}$ & $\begin{array}{l}-0.005 \\
(0.014)\end{array}$ \\
\hline House_member_size & $\begin{array}{c}-0.147^{* * *} \\
(0.007)\end{array}$ & $\begin{array}{c}-0.147^{* * *} \\
(0.005)\end{array}$ & $\begin{array}{c}-0.148^{* * *} \\
(0.007)\end{array}$ & $\begin{array}{c}-0.147^{* * *} \\
(0.007)\end{array}$ & $\begin{array}{c}-0.147^{* * * *} \\
(0.007)\end{array}$ & $\begin{array}{c}-0.190^{* * *} \\
(0.005)\end{array}$ & $\begin{array}{c}-0.188^{* * *} \\
(0.005)\end{array}$ \\
\hline Child_ratio & $\begin{array}{c}0.177 \\
(0.844)\end{array}$ & $\begin{array}{c}0.136 \\
(0.748)\end{array}$ & $\begin{array}{c}0.050 \\
(0.956)\end{array}$ & $\begin{array}{c}0.268 \\
(0.790)\end{array}$ & $\begin{array}{c}0.291 \\
(0.773)\end{array}$ & $\begin{array}{l}0.031^{* *} \\
(0.013)\end{array}$ & $\begin{array}{l}0.034^{* * * *} \\
(0.013)\end{array}$ \\
\hline Elder_ratio & $\begin{array}{l}-0.139 \\
(0.481)\end{array}$ & $\begin{array}{c}0.020 \\
(1.020)\end{array}$ & $\begin{array}{c}0.401 \\
(0.527)\end{array}$ & $\begin{array}{l}-0.473 \\
(0.577)\end{array}$ & $\begin{array}{l}-0.587 \\
(0.637)\end{array}$ & $\begin{array}{c}-0.043^{* * *} \\
(0.013)\end{array}$ & $\begin{array}{c}-0.048^{* * * *} \\
(0.013)\end{array}$ \\
\hline Risk prefer & $\begin{array}{c}0.001 \\
(0.018)\end{array}$ & $\begin{array}{c}0.001 \\
(0.016)\end{array}$ & $\begin{array}{c}0.001 \\
(0.018)\end{array}$ & $\begin{array}{c}0.001 \\
(0.018)\end{array}$ & $\begin{array}{c}0.002 \\
(0.018)\end{array}$ & $\begin{array}{l}0.038^{* *} \\
(0.016)\end{array}$ & $\begin{array}{l}0.038^{* *} \\
(0.016)\end{array}$ \\
\hline Risk averse & $\begin{array}{c}-0.041^{* * * *} \\
(0.012)\end{array}$ & $\begin{array}{c}-0.041^{* * *} \\
(0.011)\end{array}$ & $\begin{array}{c}-0.041^{* * * *} \\
(0.012)\end{array}$ & $\begin{array}{c}-0.041^{* * * *} \\
(0.012)\end{array}$ & $\begin{array}{c}-0.041^{* * * *} \\
(0.012)\end{array}$ & $\begin{array}{c}-0.111^{* * *} \\
(0.011)\end{array}$ & $\begin{array}{c}-0.109^{* * *} \\
(0.010)\end{array}$ \\
\hline Unhealthy members & $\begin{array}{l}-0.134 \\
(0.841)\end{array}$ & $\begin{array}{l}-0.093 \\
(1.057)\end{array}$ & $\begin{array}{l}-0.004 \\
(0.953)\end{array}$ & $\begin{array}{l}-0.229 \\
(0.788)\end{array}$ & $\begin{array}{l}-0.250 \\
(0.770)\end{array}$ & $\begin{array}{c}-0.035^{* * *} \\
(0.008)\end{array}$ & $\begin{array}{c}-0.034^{* * * *} \\
(0.008)\end{array}$ \\
\hline Rural & $\begin{array}{c}0.008 \\
(0.037)\end{array}$ & $\begin{array}{c}0.008 \\
(0.026)\end{array}$ & $\begin{array}{l}0.005 \\
(0.037)\end{array}$ & $\begin{array}{c}0.009 \\
(0.037)\end{array}$ & $\begin{array}{c}0.011 \\
(0.037)\end{array}$ & $\begin{array}{c}-0.251^{* * *} \\
(0.016)\end{array}$ & $\begin{array}{c}-0.245^{* * * *} \\
(0.016)\end{array}$ \\
\hline Ln_per_GDP & $\begin{array}{c}0.376^{* * *} \\
(0.085)\end{array}$ & $\begin{array}{l}0.369^{* * * *} \\
(0.065)\end{array}$ & $\begin{array}{c}0.328^{* * *} \\
(0.088)\end{array}$ & $\begin{array}{c}0.392^{* * *} \\
(0.087)\end{array}$ & $\begin{array}{l}0.379^{* * * *} \\
(0.087)\end{array}$ & $\begin{array}{l}-0.015 \\
(0.040)\end{array}$ & $\begin{array}{l}-0.034 \\
(0.031)\end{array}$ \\
\hline $\begin{array}{l}\text { Financial } \\
\text { development level }\end{array}$ & $\begin{array}{l}0.269^{* * * *} \\
(0.052)\end{array}$ & $\begin{array}{l}0.260^{* * *} \\
(0.041)\end{array}$ & $\begin{array}{l}0.261^{* * * *} \\
(0.053)\end{array}$ & $\begin{array}{l}0.277^{* * * *} \\
(0.053)\end{array}$ & $\begin{array}{l}0.264^{* * * *} \\
(0.054)\end{array}$ & $\begin{array}{c}0.000 \\
(0.036)\end{array}$ & $\begin{array}{l}0.131^{\text {**** }} \\
(0.032)\end{array}$ \\
\hline $\begin{array}{l}\text { Observations } \\
\text { R-squared }\end{array}$ & $\begin{array}{c}66789 \\
0.069\end{array}$ & $\begin{array}{c}66789 \\
0.069\end{array}$ & $\begin{array}{c}66789 \\
0.069\end{array}$ & $\begin{array}{c}66789 \\
0.069\end{array}$ & $\begin{array}{c}66789 \\
0.069\end{array}$ & $\begin{array}{l}23070 \\
0.537\end{array}$ & $\begin{array}{c}23070 \\
0.539\end{array}$ \\
\hline $\begin{array}{l}\text { F value of First } \\
\text { stage }\end{array}$ & & 56268.28 & & & & & \\
\hline
\end{tabular}




Wald test $2.12 \mathrm{e}+07(0.000)$
Notes: $*, * *$ and $* * *$ respectively indicate significance at the level of $10 \%, 5 \%$ and $1 \%$; words in brackets mean the
standard deviation of heteroskedasticity-robust of the cluster at the municipal level; what is reported in the table is
the estimated marginal effect. Hereinafter the same.
Because we use the index data with two years lag in the regression, and the start year of investment index data is
2014 and credit investigation index data is 2015 , which means these two index data could only be matched with the
2017 CHFS data. Thus, in the regression of investment index and credit investigation index on household
consumption, we only use the 2017 CHFS data in which the observations are 23070 .

Table 4. Heterogeneous Impact of the Digital Finance on Household Consumption

\begin{tabular}{|c|c|c|c|c|}
\hline & $(1)$ & $(2)$ & $(3)$ & (4) \\
\hline Index of digital finance & $\begin{array}{c}0.054 \\
(0.034)\end{array}$ & $\begin{array}{c}0.012 \\
(0.036)\end{array}$ & $\begin{array}{c}0.047 \\
(0.036)\end{array}$ & $\begin{array}{c}0.106^{\text {**** }} \\
(0.033)\end{array}$ \\
\hline Index of digital finance \#lower asset & $\begin{array}{c}0.061^{* * *} \\
(0.015)\end{array}$ & & & \\
\hline Index of digital finance \#lower income & & $\begin{array}{c}0.067^{* * *} \\
(0.014)\end{array}$ & & \\
\hline Index of digital finance \#lower financial literacy & & & $\begin{array}{c}0.039^{* * *} \\
(0.013)\end{array}$ & \\
\hline Index of digital finance \# third-tier and fourth-tier city & & & & $\begin{array}{c}0.046^{\text {*** }} \\
(0.017)\end{array}$ \\
\hline Control & Yes & Yes & Yes & Yes \\
\hline Observations & 42658 & 42658 & 42088 & 66789 \\
\hline R-squared & 0.049 & 0.062 & 0.069 & 0.069 \\
\hline
\end{tabular}

Notes: the control variables are the same as Table 2. Hereinafter the same.

To divide the household sample more reasonably in these three regressions, we use the balanced panel data which means every single household sample existed in 2013, 2015 and 2017. And in the baseline regression, we use the unbalanced panel data. Thus, the observations in column (1) and (2) are both 42658 which is less than the baseline regression of 66789. As for column (3), the observations are 42088 which are less than those in column (1) and (2) because there are missing values for financial literacy. 
Table 5. Eight Categories of Household Consumption

\begin{tabular}{lccccccccc}
\hline & Food & Clothing & $\begin{array}{c}\text { House } \\
\text { maintenance }\end{array}$ & $\begin{array}{c}\text { Daily } \\
\text { necessities } \\
\text { and durables }\end{array}$ & $\begin{array}{c}\text { Transportation and } \\
\text { communication }\end{array}$ & $\begin{array}{c}\text { Medical } \\
\text { care }\end{array}$ & $\begin{array}{c}\text { Entertainment } \\
\text { and education }\end{array}$ & Others \\
\hline & $(1)$ & $(2)$ & $(3)$ & $(4)$ & $(5)$ & $(6)$ & $(7)$ & $(8)$ \\
\hline Index of & $0.098^{*}$ & $0.663^{* * *}$ & $0.140^{* *}$ & $-1.239^{* * * *}$ & -0.021 & $0.454^{* * *}$ & $2.618^{* * *}$ & $-0.602^{* * *}$ \\
digital finance & $(0.051)$ & $(0.121)$ & $(0.063)$ & $(0.140)$ & $(0.069)$ & $(0.197)$ & $(0.257)$ & $(0.133)$ \\
\hline Control & Yes & Yes & Yes & Yes & Yes & Yes & Yse & Yes \\
\hline Observations & 66789 & 66789 & 66789 & 66789 & 66789 & 66789 & 66789 & 66789 \\
R-squared & 0.055 & 0.033 & 0.020 & 0.037 & 0.050 & 0.005 & 0.041 & 0.011 \\
\hline
\end{tabular}

Table 6. Consumption Structure

\begin{tabular}{lcccc}
\hline & $\begin{array}{c}\text { Recurring } \\
\text { household } \\
\text { consumption }\end{array}$ & $\begin{array}{c}\text { Non-recurring } \\
\text { household } \\
\text { consumption }\end{array}$ & $\begin{array}{c}\text { Proportion of recurring } \\
\text { household consumption }\end{array}$ & $\begin{array}{c}\text { Proportion of } \\
\text { non-recurring household } \\
\text { consumption }\end{array}$ \\
\hline Index of digital & $(1)$ & $(2)$ & $(3)$ & $(4)$ \\
inclusive finance & $0.157^{* * *}$ & $-1.030^{* * *}$ & $0.047^{* * *}$ & $-0.047^{* * *}$ \\
Control & $(0.039)$ & $(0.160)$ & $(0.018)$ & $(0.015)$ \\
\hline Observations & Yes & Yes & Yes & Yes \\
R-squared & 66789 & 66789 & 66789 & 66789 \\
\hline
\end{tabular}

Table 7. Online Shopping

\begin{tabular}{lccc}
\hline & $\begin{array}{c}\text { Per capita household consumption } \\
\text { expenditure }\end{array}$ & $\begin{array}{c}\text { Online } \\
\text { shopping }\end{array}$ & $\begin{array}{c}\text { Per capita household } \\
\text { consumption expenditure }\end{array}$ \\
\hline & $(1)$ & $(2)$ & $(3)$ \\
\hline $\begin{array}{l}\text { Index of digital inclusive } \\
\text { finance }\end{array}$ & $0.451^{* * *}$ & $0.108^{* * *}$ & $0.420^{* * *}$ \\
& $(0.054)$ & $(0.021)$ & $(0.054)$ \\
Online shopping & & & $0.289^{* * *}$ \\
& & Yes & $(0.010)$ \\
Control & Yes & 23070 & Yes \\
\hline Observations & 23070 & 0.318 & 23070 \\
R-squared & 0.540 & $7.779(0.000) / 8.37 \%$ & 0.557 \\
Sobel test & & \multicolumn{3}{c}{} \\
\hline
\end{tabular}


Table 8. Digital Payment

\begin{tabular}{lccc}
\hline & $\begin{array}{c}\text { Per capita household consumption } \\
\text { expenditure }\end{array}$ & $\begin{array}{c}\text { Digital } \\
\text { payment }\end{array}$ & $\begin{array}{c}\text { Per capita household } \\
\text { consumption expenditure }\end{array}$ \\
\hline Index of digital inclusive & $(1)$ & $(2)$ & $(3)$ \\
finance & $0.451^{* * *}$ & $0.166^{* * *}$ & $0.410^{* * *}$ \\
& $(0.054)$ & $(0.030)$ & $(0.051)$ \\
Digital payment & & & $0.245^{* * *}$ \\
& & Yes & $(0.011)$ \\
Control & Yes & 23070 & Yes \\
\hline Observations & 23070 & 0.327 & 23070 \\
R-squared & 0.540 & $10.860(0.000) / 10.58 \%$ & 0.552 \\
Sobel test & & \multicolumn{3}{c}{} \\
\hline
\end{tabular}

Table 9. Online Credit

\begin{tabular}{lccc}
\hline & $\begin{array}{c}\text { Per capita household consumption } \\
\text { expenditure }\end{array}$ & $\begin{array}{c}\text { Online } \\
\text { credit }\end{array}$ & $\begin{array}{c}\text { Per capita household consumption } \\
\text { expenditure }\end{array}$ \\
\hline Index of digital inclusive & $(1)$ & $(2)$ & $(3)$ \\
finance & $0.451^{* * *}$ & $0.033^{* * *}$ & $0.445^{* * *}$ \\
& $(0.054)$ & $(0.010)$ & $(0.054)$ \\
Online credit & & & $0.170^{* * *}$ \\
& & Yes & $(0.015)$ \\
Control & Yes & 23070 & Yes \\
\hline Observations & 23070 & 0.120 & 23070 \\
R-squared & 0.540 & $4.659(0.000) / 1.91 \%$ & 0.542 \\
Sobel test & & & \\
\hline
\end{tabular}

Table 10. Internet Financing

\begin{tabular}{lccc}
\hline & $\begin{array}{c}\text { Per capita household consumption } \\
\text { expenditure }\end{array}$ & $\begin{array}{c}\text { Internet } \\
\text { financing }\end{array}$ & $\begin{array}{c}\text { Per capita household consumption } \\
\text { expenditure }\end{array}$ \\
\hline Index of digital inclusive & $(1)$ & $(2)$ & $(3)$ \\
finance & $0.451^{* * *}$ & $0.028^{* * *}$ & $0.447^{* * *}$ \\
& $(0.054)$ & $(0.013)$ & $(0.054)$ \\
Internet financing & & & $0.140^{* * *}$ \\
& & Yes & $(0.013)$ \\
Control & Yes & 23070 & Yes \\
\hline Observations & 23070 & 0.152 & 23070 \\
R-squared & 0.540 & $5.305(0.000) / 2.22 \%$ & 0.542 \\
Sobel test & & & \\
\hline
\end{tabular}


Table 11. Commercial Insurance Purchasing

\begin{tabular}{lccc}
\hline & $\begin{array}{c}\text { Per capita household } \\
\text { consumption expenditure }\end{array}$ & $\begin{array}{c}\text { Commercial } \\
\text { insurance } \\
\text { purchasing }\end{array}$ & $\begin{array}{c}\text { Per capita household } \\
\text { consumption expenditure }\end{array}$ \\
\hline $\begin{array}{l}\text { Index of digital inclusive } \\
\text { finance }\end{array}$ & $(1)$ & $(2)$ & $(3)$ \\
Commercial insurance & $0.451^{* * * *}$ & $0.057^{* *}$ & $0.442^{* * *}$ \\
purchasing & $(0.054)$ & $(0.023)$ & $(0.054)$ \\
Control & & & $0.146^{* * *}$ \\
Observations & Yes & Yes & $(0.010)$ \\
R-squared & 23070 & 23070 & Yes \\
Sobel test & 0.540 & 0.078 & 23070 \\
\hline
\end{tabular}

Table 12. Robustness Check_County level of index

\begin{tabular}{|c|c|c|c|c|c|c|}
\hline & (1) & (2) & (3) & (4) & (5) & (6) \\
\hline $\begin{array}{l}\text { Total index of digital inclusive } \\
\text { finance }\end{array}$ & $0.147^{* * *}$ & & & & & \\
\hline & $(0.013)$ & & & & & \\
\hline Index of coverage breadth & & $\begin{array}{l}0.150^{* * * *} \\
(0.013)\end{array}$ & & & & \\
\hline Index of use depth & & & $\begin{array}{c}0.208^{* * *} \\
(0.019)\end{array}$ & & & \\
\hline Index of insurance & & & & $\begin{array}{c}0.066^{* * * *} \\
(0.007)\end{array}$ & & \\
\hline Index of investment & & & & & $\begin{array}{c}0.266^{* * *} \\
(0.028)\end{array}$ & \\
\hline Index of credit investigation & & & & & & $\begin{array}{c}0.372^{* * *} \\
(0.041)\end{array}$ \\
\hline Control & Yes & Yes & Yes & Yes & Yes & Yes \\
\hline Observations & 23070 & 23070 & 23070 & 23070 & 23070 & 23070 \\
\hline R-squared & 0.541 & 0.541 & 0.540 & 0.539 & 0.539 & 0.539 \\
\hline
\end{tabular}




\section{Table 13. Robustness Check_Household consumption rate}

\begin{tabular}{|c|c|c|c|c|c|c|}
\hline & (1) & (2) & (3) & (4) & (5) & (6) \\
\hline $\begin{array}{l}\text { Total index of digital inclusive } \\
\text { finance }\end{array}$ & $0.032^{* *}$ & & & & & \\
\hline & $(0.013)$ & & & & & \\
\hline Index of coverage breadth & & $\begin{array}{l}0.052^{* *} \\
(0.022)\end{array}$ & & & & \\
\hline Index of use depth & & & $\begin{array}{l}0.018^{* *} \\
(0.007)\end{array}$ & & & \\
\hline Index of insurance & & & & $\begin{array}{l}0.004^{* *} \\
(0.002)\end{array}$ & & \\
\hline Index of investment & & & & & $\begin{array}{l}0.100^{* * *} \\
(0.020)\end{array}$ & \\
\hline Index of credit investigation & & & & & & $\begin{array}{c}0.087^{* * *} \\
(0.013)\end{array}$ \\
\hline Control & Yes & Yes & Yes & Yes & Yes & Yes \\
\hline Observations & 37705 & 37705 & 37705 & 37705 & 14017 & 14017 \\
\hline R-squared & 0.305 & 0.305 & 0.305 & 0.305 & 0.284 & 0.285 \\
\hline
\end{tabular}

Note:

Considering the stability of data, we use the samples of household consumption rate between 0 and 1 . Thus, the observations in column (1),(2),(3) and (4) are 37705 which are less than the baseline regression of 66789. The same reason as the column (5) and (6) of table 3, column (5) and (6) only use the 2017 CHFS data in which the observations are 14017. 